\title{
sciendo
}

RESEARCH PAPERS FACULTY OF MATERIALS

SCIENCE AND TECHNOLOGY IN TRNAVA

SLOVAK UNIVERSITY OF TECHNOLOGY

IN BRATISLAVA

2018, Volume 26, Number 42

DOI 10.2478/rput-2018-0007

\section{PRODUCTION SYSTEMS PLANNING AND DATABASES IN ASSEMBLY}

\author{
Šimon LECKÝ, Štefan VÁCLAV, Dávid MICHAL, Martin NECPAL \\ SLOVAK UNIVERSITY OF TECHNOLOGY IN BRATISLAVA, \\ FACULTY OF MATERIALS SCIENCE AND TECHNOLOGY IN TRNAVA, \\ INSTITUTE OF PRODUCTION TECHNOLOGIES, \\ UliCA JÁnA BotTu 2781/25, 91724 TRNAVA, SLOVAK REPUBliC \\ e-mail:simon.lecky@stuba.sk, stefan.vaclav@stuba.sk,david.michal@stuba.sk, \\ martin.necpal@stuba.sk \\ Received: 29.05.2018, Accepted: 25.06.2018, Published: 19.09.2018
}

\begin{abstract}
Paper deals with the design of assembly workplaces and systems. The aim is to provide a solution to the problems in the field of the assembly systems design and planning. One of the goals is to design a solution to the design of assembly workplaces. The focus of the research is therefore a proposal of the design methodology of the assembly workplaces and systems, and thus the development of integrated methodological procedure and tools. The introductory part is devoted to the current state of assembly workplaces, assembly systems and their planning. On the basis of the theoretical knowledge, an analysis of the assembly systems and workplaces is carried out according to the pre-selected criteria. It is necessary to develop the classification of assembly systems and workplaces in terms of product or assembled entities. Individual sections of the paper are devoted to the design of databases for the needs of designing the assembly workstations and systems.
\end{abstract}

\section{Key words}

Assembly planning, assembly systems, databases

\section{INTRODUCTION}

The design of assembly workplaces and systems is a complex process that involves not only assembly technology but also material flow, information flow, workers, design and selection of premises, etc. Today, dynamic planning approaches, environment integration, and an emphasis on organization and management are essential (1).

Current requirements for assembly systems are flexibility, productivity and quality. The flexibility can be viewed from different angles: different types of products that we can produce in the given system, different production quantities, different order, speed of response to customer requirements. Productivity is often in direct conflict with the flexibility of production. The greater the variability in production, the greater the requirements for the flexibility of the 
equipment, materials and components in the warehouse, people, management, and so on. Increasing productivity means increasing outputs and reducing inputs to production. Between flexibility and productivity, it is necessary to actively seek the most appropriate compromise. In quality, the system is designed in such a way that quality is built directly into the system itself and no additional measures and costs will be needed to maintain quality (2).

The System Approach (3), understood as a way of thinking and solving problems in which complexities are understood in its external and internal contexts, applied in the design of assembly processes, is manifested in the following way:

- a thorough identification of all relevant components, phenomena, elements that are relevant to the problem,

- the ability to identify and potentially quantify all relevant interrelationships between the identified elements,

- it is the basis for modeling different types and types, which are a prerequisite for the application of various computer-aided simulation and rationalization activities.

This approach was also used by Deutschlander for his computer aided system in the area of linear assembly workstations and systems planning (7).

\section{ASSEMBLY PLANNING}

Preparation phase includes the processes such as design of the assembly structure, updating the information base, formulation of the problem and objective. The main step of this phase is to enter the problem and clearly define the goal or solution that is required.

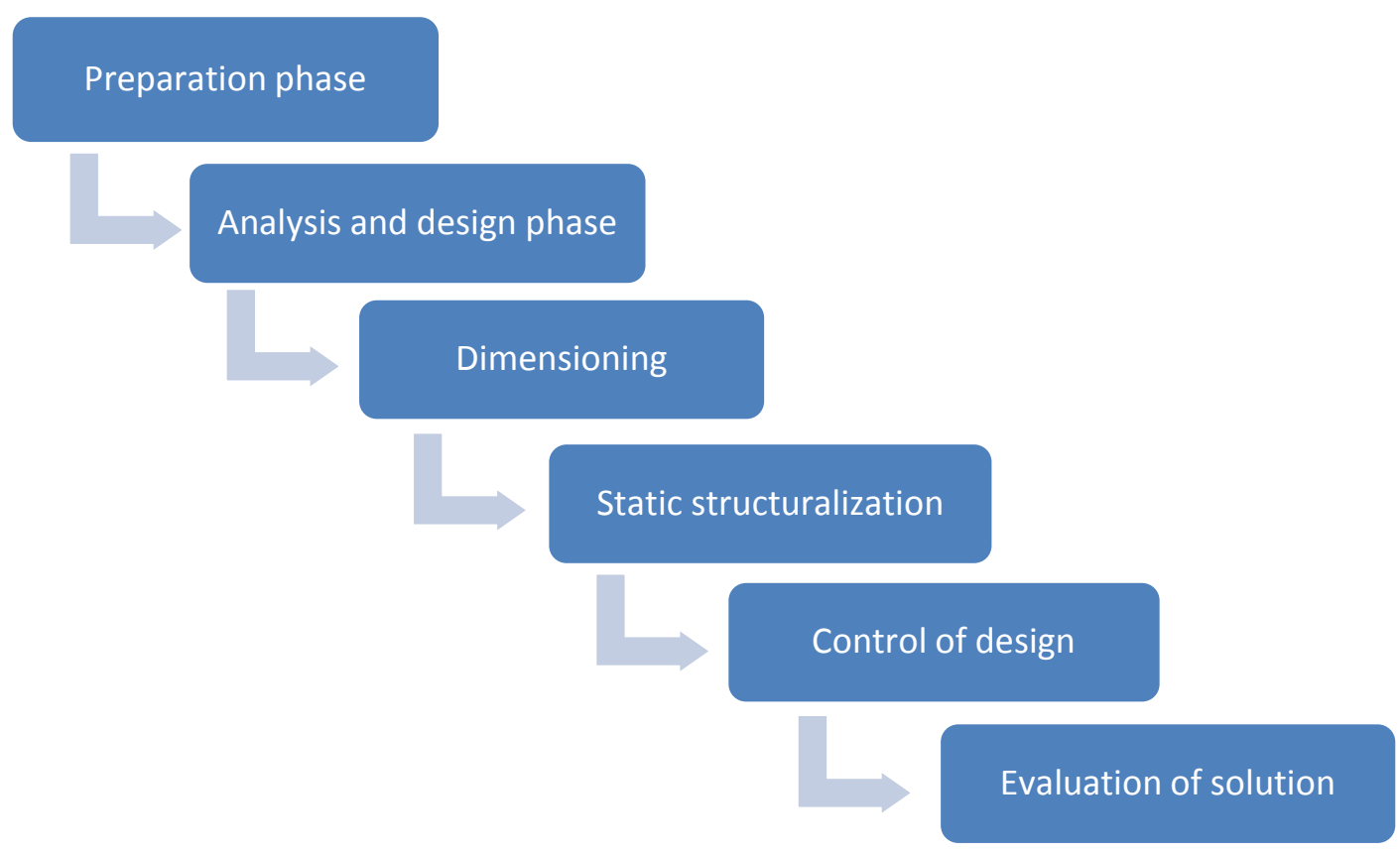

Fig. 1 Basic phases of planning (4)

Analytical and design phases address the field of analysis of existing state, inventory and component analysis, verification of used technology, design of technology and organization of the assembly process. 
Dimensioning is a phase where major gross calculations are made, whether component/ material consumption, assembly batches or conveyors, as well as capacity conversions of machines, workers, areas, energy and prices.

Static structuring solves the transport and handling of parts, assemblies or preparations, the location of machines, robotic workplaces, etc. Equally, this phase includes analysis of information flows and design of the management system.

Control of the proposed layout deals with design of assembly operations, analytical modeling and especially simulation of the assembly system.

Assessment and Completion Phase includes cost efficiency, budget, data preparation, text and graphical parts of the project (5).

In order to assess the economic efficiency of the whole project, it is necessary to have a lot of concrete data on the entire project. The requirements for the technical parameters of the production and thus of the machinery are not in sharp contrast to the requirement to minimize the costs of implementing the project (5).

Another division of the design of the assembly systems into the phase is the division of the project into the following three phases:

- Analysis of the problem and setting the objectives of the project,

- Conceptual, varied design,

- Detailed design and implementation.

\section{DATABASE GENERATION}

Higher profits can be achieved when the customer is offered superior quality associated with a perfect service. However, it can also be achieved by systematically cutting costs and shortening times.

When cost reduction is directed to the detection and elimination of waste in an enterprise, this process has a positive impact on changing the corporate culture, simplifying the processes, engaging the people, decentralizing, and ultimately also positively influencing the flexibility of the system (6).

The proposal for the design of assembly systems addresses design in terms of system approach in the early stages of the project. The task is to make a solution that can building the first structure of the assembly system when designing the project, thus shortening the time needed for the first design phase. Designing an assembly system is a complex problem, and there are a large number of variables and specific options that can be chosen and identified as the right solution.

Designing an algorithmic solution would shorten the design time of the assembly system, which means faster start of the next phases and design stages. Such an algorithmic solution, however, must work with information, data that exist in the assembly systems.

In the field of assembly systems and overall assembly, there are many different settings and technical solutions. Since assembly, technology, workers, surroundings and especially assembly of any other product fall under the assembly subsets, it is necessary to categorize all this information or assign the accompanying attributes to them. 


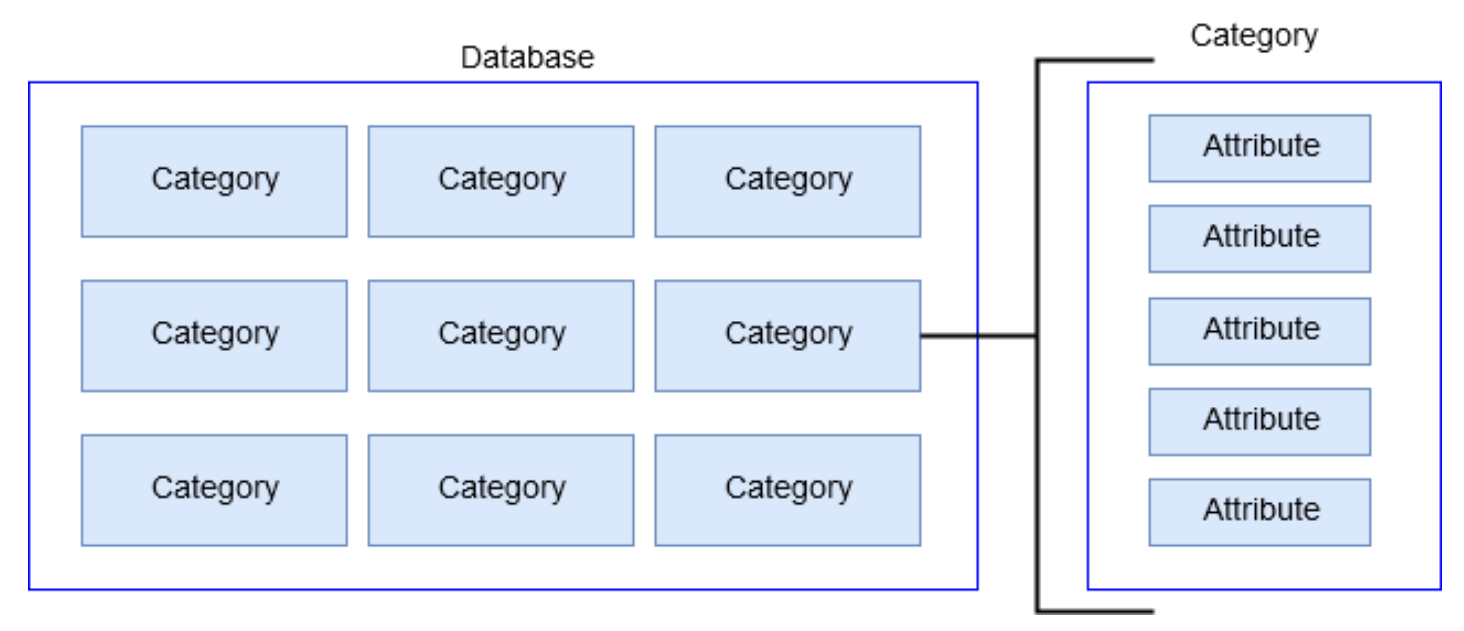

Fig. 2 Illustration of database and categories

By defining the categories, the necessary first format of the database will be obtained, which will be assigned to the individual categories. Each entry must have its own attributes or properties, the properties on which the algorithm will work. Assignment of data properties is based on practice or after discreet simulation.

Assembling workplaces and systems can be designed in two ways:

- from down to up,

- from up to down.

For "down to up" and "up to down" design, the same database should be used for designing. This can be ensured by assigning such features to data that will focus on component requirements as well as requirements for the installation system.

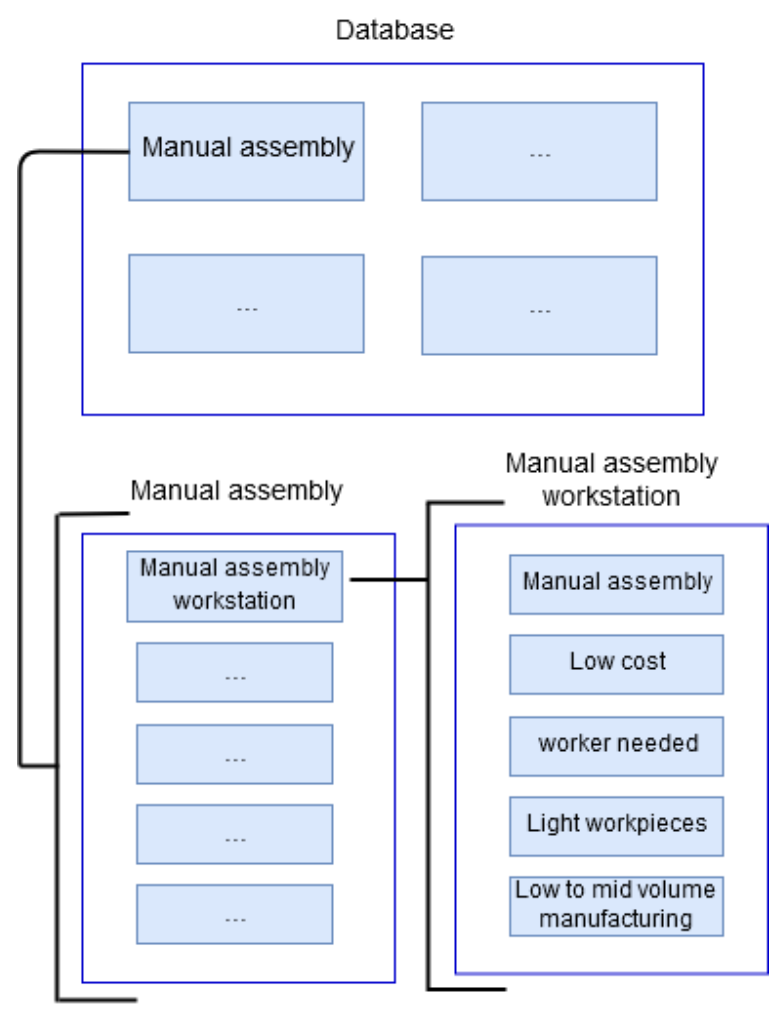

Fig. 3 Illustration of manual assembly in database 


\section{CONCLUSION}

In this paper, the design of building databases used in the product-based approach or assembly workstation requirements approach or assembly system approach is described. In future, databases will be used in the field of assembly systems to reduce design times.

The next item that is needed for good software solution is an algorithm. Algorithm is needed for the database management. The information stored in each category must be accessible by algorithm. The algorithm should work with the database and to deliver desirable solution for the assembly system planning team.

After verifying the functionality of the design idea, it is possible to develop a software solution. Incorporating the entire proposed database solution into the software can have a positive effect for practice, especially in terms of simplicity and application for the user. Software solutions which use databases for planning processes can save expenses and shorten the time needed for the assembly systems planning.

\section{Acknowledgement}

The article was written as part of the Young Researcher Project 1325 "Analysis and planning of assembly systems and workstations with the use of discrete event simulation in industry" supported by the scientific program - Motivation and support in quality and effectivity elevation of young researchers and scientists.

\section{References:}

1. MANLING, F. 2013. Projektováni výrobnich systémů. (Planning the manufacturing systems.) EduCom CZ.1.07/2.2.00/15.0089. cit [2018-03-03]. Available on the Internet: http://educom.tul.cz/educom/inovace/VSY_II/

2. IPA Slovakia, Projektování výrobnich systémů. (Manufacturing systems planning). (C2018 [cit. 2018.04.04]. Available on the Internet: www.ipaslovakia.sk

3. JONES, J.CH. 1982. Design methods. New York, John Wiley and Sons

4. ZELENKA, A., KRÁL. 1995. Projektování výrobnich systémů. (Manufacturing project planning). Prague: ČVUT.

5. BARÁNEK, I., FICZERE, P., CHARBULA, J., KICKO, J. 1990. Výrobné stroje a nástroje. (Manufacturing machines and tools.) Bratislava, SVŠT. ISBN 80-227-0265-X

6. BANGSOW, S. 2011. Tecnomatix Plant Simulation: Modeling and programming by means of examples. England: London. ISBN 978-3-319-19502-5

7. DEUTSCHLÄNDER, A. 1989. Integrierte rechnerunterstützte Montageplannung. (Integrated computer-assisted assembly planning.) (Dissertation thesis). Munich. Hanser,

\section{ORCID:}

Štefan Václav 0000-0003-3266-3645

Martin Necpal 0000-0003-2142-9204 